\title{
Limoniastrum monopetalum (L.) Boiss, a candidate plant for use in urban and suburban areas with adverse conditions. An anatomical and histochemical study.
}

\author{
Anastasia AKOUMIANAKI-IOANNIDOU*1, R. P. SPENTZA ${ }^{1}$ C. FASSEAS ${ }^{2}$ \\ ${ }^{1}$ Laboratory of Floriculture and Landscape Architecture ${ }^{2}$ Laboratory of Electron Microscopy \\ Agricultural University of Athens, Iera Odos 75, 11855 Athens Greece \\ *)Corresponding author, e-mail: akouman@aua.gr
}

BulletinUASVM Horticulture 72(2) / 2015

Print ISSN 1843-5254, Electronic ISSN 1843-5394

DOI:10.15835/buasvmcn-hort:11347

\begin{abstract}
Limoniastrum monopetalum L. is an interesting small shrub native to Greece and other Mediterranean countries with an attractive foliage, and blooming in the summer with pink flowers. In this work an anatomical and hystochemical study of the species were carried out in order to investigate the suitability of the L. monopetalum for use in urban and suburban areas as ornamental plant and its growth in hostile environments such as archeological sites, roof gardens, landscape restoration (e.g. quarries, roadsides, etc.). The results showed that the leaves of $L$. monopetalum are amphistomatic bifacial with leaf blade approx. $170 \mu \mathrm{m}$ thick. The epidermal cells is relatively thick approximately $20 \mu \mathrm{m}$ and covered by a $2 \mu \mathrm{m}$ thick cuticle. Furthermore both surfaces of the leaves are entirely covered by salt crystals secreted by the salt glands, as this is revealed from fresh unprocessed specimens observed with the SEM.The histochemical tests showed the presence of terpenoids in the cell walls of the epidermal cells and in the leaf vascular tissues, phenolics, nitrites and alkaloids, flavonoids in the mesophyll cells, especially in the vacuoles, and lipids only in the cuticle. Both morphological anatomical and histochemical characteristics of the leaves indicate the xeromorphic character of the species which render L. monopetalum a suitable plant for ornamental use in a wide spectrum of areas with adverse conditions
\end{abstract}

Keywords: halophytes, salt glands, phenolics, flavonoids, landscape restoration.

\section{Introduction}

L. monopetalum (L.) Boiss, (Plumbaginaceae) is an evergreen shrub native to Greece and also found in other Mediterranean countries with dense foliage reaching a height of $0.3-1.0 \mathrm{~m}$, with many branching shoots. Its foliage is greengray and it blooms in the summer which are initially pink and turning violet at the end of the blooming season (Blamey \& Grey-Wilson, 1993). L. monopetalum is a typical halophyte using the strategy of salt absorption and secretion through specialized structures on their leaves, the salt glands. L. monopetalum is also recommended for use for phytoremediation of soils polluted with $\mathrm{Cd}$ and $\mathrm{Pb}$ (Manousaki et al. 2014).

\section{Aims and Objectives}

Due to the ornamental characteristics and properties of L. monopetalum the anatomy and histochemistry of its leaves were investigated in order to assess the plant's suitability as ornamental for urban and suburban areas and its growth in problematic places such as archeological sites, roof gardens etc.

\section{Materials and Methods}

Light and scanning electron microscopy (SEM) were used for the study of the morphology, anatomy and histochemistry of L. monopetalum leaves which were collected from naturally 
grown plants from the Island of Milos. For light microscopy and histochemistry (bright field and fluorescence), transverse sections of approximately $25 \mu \mathrm{m}$ thickness were cut with a cryotome and stained with Nadi reagent for the detection of phenolics, Sudan IV (Jensen, 1962) for lipids, Dragendorff reagent for alkaloids, and $\mathrm{AlCl}_{3}$ (Guerin et al., 1971) for the enhancement of fluorescence of flavonoids. The samles were observed and photographed with an Olympus BX40 light microscope, equipped with an Olympus DP21 digital camera. For SEM observations small pieces of leaves (5X5 mm) were fixed in 3\% glutaraldehyde in $0.1 \mathrm{M}$ phosphate buffer at $\mathrm{pH}$ 7.2, washed in buffer, dehydrated in a series of acetone, critical point dried and sputter coated with gold. Samples were observed with a Jeol 6063 SEM. Some samples were examined fresh without any prior treatment. The thickness of the leaves, epidermis and cuticle were measured, as well as the number of stomata was counted from ten different photographs and mean values were calculated.

\section{Results and Discussion}

The leaves of $L$. monopetalum are amphistomatic and bifacial with a single layer of epidermal cells. The leaf blade is approx. 170 $\mu \mathrm{m}$ thick (Fig. 2A,B); on both sides the outer cell wall of epidermal cells is relatively thick, approx. $20 \mu \mathrm{m}$ and covered by a $2 \mu \mathrm{m}$ thick cuticle (Fig. 2C). Stomata are of the anamocytic type and their number is the same on both sides of the leaf which is $97 \pm 2 \mathrm{st} / \mathrm{mm}^{2}$ (Fig. 1A,B). A number of irregularly shaped astrosclereids appear in the mesophyll with their size varying between $50-100 \mu \mathrm{m}$ in length (Fig. 2A). Both surfaces of the leaves are entirely covered by salt crystals apparently secreted by the salt glands, as this is revealed from fresh unprocessed specimens observed with the SEM (Fig. 1B). The salt glands were approximately $6 / \mathrm{mm}^{2}$, with a diameter of $100-300 \mu \mathrm{m}$. These anatomical features are characteristic of a xerophytic halophyte using the strategy of salt absorption and secretion through specialized structures on their leaves, the salt glands. The presence of large astrosclereids, the thick outer cell wall of the epidermal cells and the presence of salt on their surfaces protects them from the herbivores (Fahn, 1990).

The histochemical tests showed the presence of, terpenoids in the cell walls of the epidermal cells and in the leaf vascular tissues, phenolics, nitrites and alkaloids, flavonoids in the mesophyll cells, especially in the vacuoles, and lipids only in the cuticle (Fig. A-D). The presence of phenolics in this plant has also been verified by chemical analysis methods (Trabelsi et al.,l 2010). All these secondary metabolites contribute to the chemical defense against biotic and abiotic factors.

\section{Conclusions}

All these structural and chemical characteristics providing defense and protection seem to render L. monopetalum suitable for use in almost extreme environmental conditions such as drought, high salinity, high light intensity, and high temperatures as well as protection from
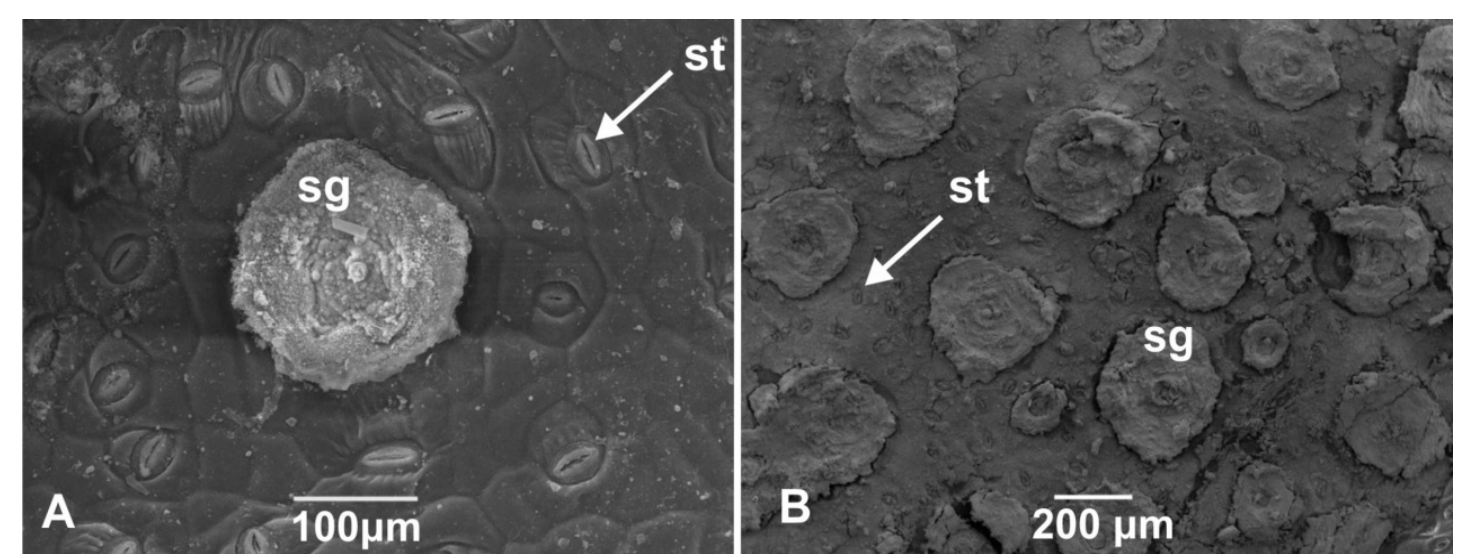

Figure 1. SEM from the leaf surface of L. monopetalum. A. processed sample. Due to the processing the salt deposits have been rinsed off. B. fresh, unprocessed sample where the leaf surface is covered with salt, secreted by the salt glands. sg: salt gland, st: stoma. 

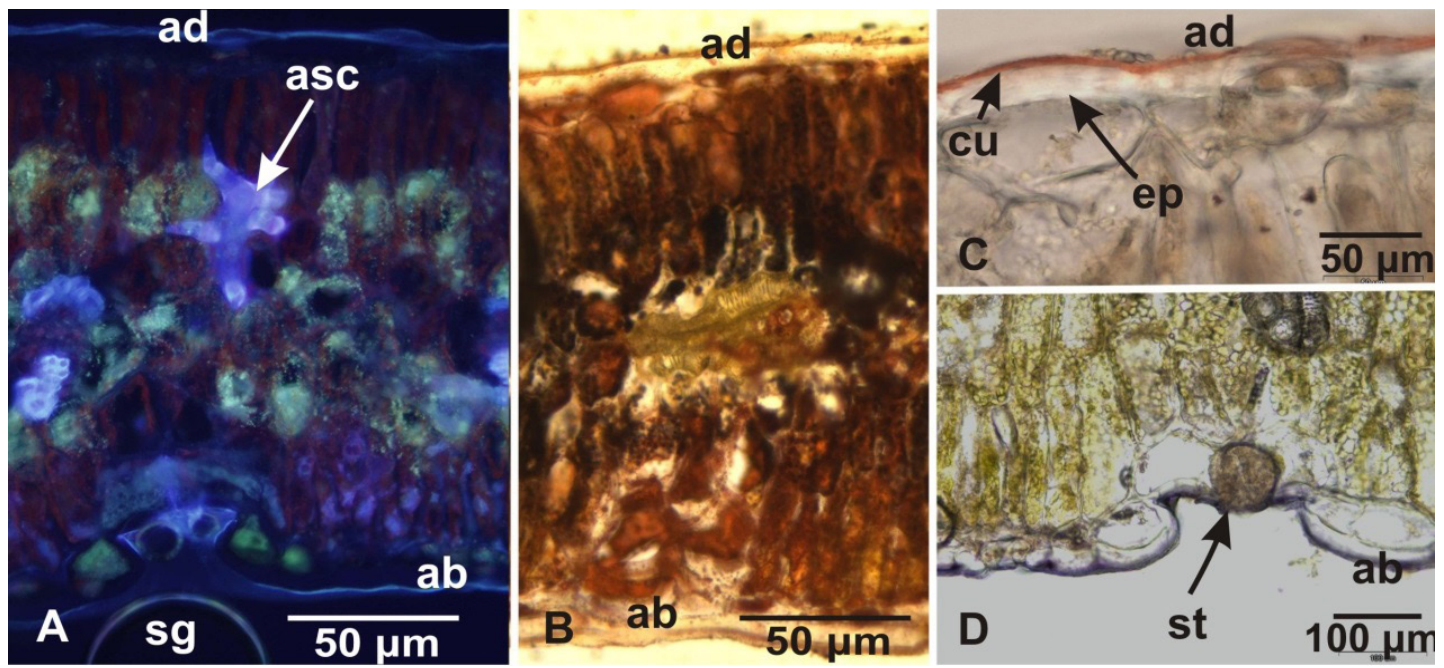

Figure 2. Transverse sections of L. monopetalum leaves as observed with fluorescence microscopy (A), yellow green and blue fluorescence is emitted by flavonoids; stained with Dragendorff reagent (B) reddish-orange colour indicates alkaloids; Sudan IV (C) stains red lipids, in this case the cuticle and Nadi reagent (D) stains purple terpenoid substances (epidermal cell walls and vascular tissue). ad: adaxial side of leaf, ab: abaxial side of leaf, asc: astrosclereid, sg: salt gland, ep: cell wall of epidermal cells, cu: cuticle.

herbivores and therefore suitable for ornamental use in modern urban and suburban areas such as archeological sites, restoration of quarries, roof gardens, and other disturbed areas.

\section{REFERENCES}

1. Blamey M and Grey-Wilson C (1993). Mediterranean Wild Flowers. Mandarin offset.

2. Fahn, A (1990). Plant Anatomy. Pergamon Press, New York.

3. Guerin HP, Delaveau PG and Paris RR (1971). Localisations histochimiques. II Procedes simples de localization de pigments flavoniques. Application a quelques Phanerogrammes. B Soc Bot Fr 118: 29-36.

4. Jensen WA (1962). Botanical Histochemistry_Principles and Practice. 1rst Edition.W.H. Freeman and Company.

5. Manousaki E, Galanaki K, Papadimitriou L and Kalogerakis N (2014). Metal Phytoremediation by the Halophyte Limoniastrum monopetalum (L.) Boiss: Two Contrasting Ecotypes. Int J Phytoremediation 16:755-769.

6. Trabelsi N, Megdiche W, Ksouri R, Falleh H, Oueslati S, Soumaya B, Hajlaoui H, Abdelly C (2010). Solvent effects phenolic contents and biological activities of the halophyte Limoniastrum monopetalum leaves. LWT-Food Sci. Techn., 43: 632-639. 